\title{
Antibody response of fibrocystic patients to homologous 0-typable and 0-defective isolates of Pseudomonas aeruginosa
}

\author{
J MacDougall, M E Hodson, T L Pitt
}

\begin{abstract}
Antibody titres to Pseudomonas aeruginosa of sera from 60 adult fibrocystic patients were determined in an enzyme linked immunosorbent assay (ELISA) with whole cells of homologous isolates which had been classified according to 0 -antigen state by their reactivity with 0-typing antisera. Patients who were continuously colonised with $P s$ aeruginosa gave the highest titres: range 1500-64000 (mean 11000) and 500-48000 (mean 9000) with homologous 0-typable and 0 -defective isolates, respectively. Lower titres to both varieties of isolates were obtained with recently colonised patients, and non-colonised patients gave titres with reference laboratory strains marginally above those of healthy controls. Serum titres of patients with sequential isolates were strain dependent and did not correlate with the 0 -antigen state of the strain. Sodium dodecyl sulphate-polyacrylamide gel electrophoresis (SDS-PAGE) and immunoblot analysis of these sera and strains showed antibody binding primarily to high molecular weight 0 repeating units of lipopolysaccharide.

It is concluded that the 0 -antigen of the strain of $P s$ aeruginosa used in the ELISA test does not influence the titre obtained with fibrocystic sera, and it is recommended that serum titres should be assessed with a panel of homologous isolates from patients.
\end{abstract}

Division of Hospital Infection, Central Public Health Laboratory,

61 Colindale Avenue, London NW9

J MacDougall T L Pitt

Department of Cystic Fibrosis, National Heart and Lung Institute, Brompton Hospital, London ME Hodson

T L Pitt

Correspondence to: Dr T L Pitt

Accepted for publication

1 March 1990
The lungs of patients with cystic fibrosis are frequently colonised with or infected by Pseudomonas aeruginosa despite the fact that serum antibodies, often in high titre, towards the organism and its products are evident. ${ }^{1-3}$ Approaches to the choice of test antigens vary considerably among laboratories but there is general agreement that antibody titres to $P S$ aeruginosa antigens rise when the infection progresses to a chronic state. The apparent decrease of titres to somatic antigens after trasts, however, with the finding that serum titres to Pseudomonas exoproteins are not influenced by exacerbations of pulmonary infection or antibiotic regimens. ${ }^{5}$ This contradiction may be due to the choice of strain or antigen for the determination of antibody treatment, as described by Brett et al, ${ }^{4}$ con- in a particular patient's sera and the length of time the patient has been colonised.

Lipopolysaccharide (LPS) is the dominant structure of the outer membrane of $P S$ aeruginosa, and serotype specificity is determined by the repeating 0 -polysaccharide side chains present in smooth strains. ${ }^{6}$ Most $P s$ aeruginosa from the serum samples of patients with cystic fibrosis, however, are rough or defective in 0 -specific antigens. ${ }^{7}$ The value of using smooth test strains for the determination of serum antibody in such patients colonised with rough strains is therefore debatable. We set out to examine whether there were differences between the antibody titres of adult fibrocystic patients towards their homologous isolates, taking account of the 0 antigenic state of the strains.

\section{Methods}

Serum samples were obtained from 54 adult fibrocystic patients who were colonised or infected with $P$ s aeruginosa in their sputum and six patients who were negative for the organism by culture. A panel of six control sera from healthy subjects was also included. Sputum was liquefied by the addition of $1 \mathrm{mg} / \mathrm{ml}$ (w/v) pancreatin (BDH) and incubated at $37^{\circ} \mathrm{C}$ for two hours and plated on King's A agar $^{8}$ and Pseudomonas Isolation Agar (Difco). Non-pigmented cultures were identified as Ps aeruginosa by the scheme of King and Phillips. ${ }^{9}$

Ps aeruginosa strains were serotyped by slide agglutination with 170 -typing sera of the International Antigenic Typing Scheme ${ }^{10}$ and two serum samples towards LPS defective variants. ${ }^{11}$ LPS was prepared from an overnight tryptone soy broth culture $(5 \mathrm{ml})$ of a strain by the proteinase $\mathrm{K}$ digestion method. ${ }^{12}$ Sodium dodecyl sulphatepolyacrylamide gel electrophoresis (SDSPAGE) was carried out in $10 \%$ resolving gels. ${ }^{13}$ LPS bands in gels were detected with a modified silver stain ${ }^{14}$ with carbonate developer $(0.28 \mathrm{M}$ sodium carbonate containing $0.05 \%(\mathrm{v} / \mathrm{v})$ formaldehyde). Electrotransfer and immunoblotting were performed as described previously..$^{15}$

For the ELISA, strains were grown on tryptone soy agar overnight at $37^{\circ} \mathrm{C}$ and the growth was harvested in carbonate buffer (pH 9.6) and adjusted by dilution to an optical density of 0.06 at $600 \mathrm{~nm}$ in the same buffer. Flat-bottomed microtitre plates (Sterilin) were coated overnight at $37^{\circ} \mathrm{C}$ with $100 \mu \mathrm{l}$ of 
Table 1 ELISA titres of patients and controls toward 0-typable and 0-defective isolates of Ps aeruginosa

\begin{tabular}{lrll}
\hline & \multicolumn{3}{l}{ Mean ELISA titre (range) } \\
\cline { 2 - 4 } Patient group $(n)$ & 0-typable isolates & 0-defective isolates \\
\hline All patients $(60)$ & $9000(1000-64000)$ & $7500(500-48000)$ \\
Recently colonised ${ }^{\star}(16)$ & $3500(1000-4000)$ & $4500(1000-7000)$ \\
Continuously colonised ${ }^{\star}(38)$ & $11000(1500-64000)$ & $9000(500-48000)$ \\
Non-colonised $\dagger(6)$ & $1500(200-6400)$ & $1500(200-6400)$ \\
Controls ${ }^{\dagger}(6)$ & $200(100-400)$ & $200(100-400)$ \\
\hline
\end{tabular}

*Titre with homologous isolates recovered prior to serum date

$\dagger$ Titre with serotype strain 06 and reference 0 -defective strain. ${ }^{11}$

bacterial suspension and washed three times in phosphate buffered saline ( $\mathrm{pH} 7 \cdot 4)$ with $0.05^{\circ}{ }_{0}(\mathrm{v} / \mathrm{v})$ Tween 20 (PBST). Serum samples were diluted serially in PBST and $100 \mu \mathrm{l}$ volumes were incubated at $37^{\circ} \mathrm{C}$ for two hours. The plates were washed five times with PBST, and $100 \mu$ l of peroxidase conjugated anti-total immunoglobulin (Sigma) was added to each well and incubated for a further two hours at $37^{\circ} \mathrm{C}$. After three washes in PBST the reaction was developed with $100 \mu \mathrm{l}$ of 0 -phenylene diamine reagent (Sigma), and stopped after 15 minutes with $12.5 \%(\mathrm{v} / \mathrm{v})$ sulphuric acid, and the absorbance read at $450 \mathrm{~nm}$. Serum specimens were tested in duplicate and repeated on at least one occasion. Batch variation was controlled by the use of a standard rabbit antiserum (anti06) and a whole cell suspension of the homologous serotype strain which gave reproducible absorbance values. The titre of a patient's serum was taken as the reciprocal of the dilution of serum which gave $50 \%$ of the maximum absorbance obtained with the standard rabbit serum.

\section{Results}

Representative colonies from primary plates of sputum specimens were purified and serotyped. Fifty two of the $\mathbf{5 4}$ culture positive patients were colonised with serologically unclassified strains-that is, they were either not agglutinated by any of the 0-sera (not typable) or gave multiple reactions with three or more sera (polyagglutinable). All unclassified strains reacted with sera to 0 -defective

Table 2 Serum ELISA titres of patients with homologous isolates of Ps aeruginosa

\begin{tabular}{|c|c|c|c|c|c|}
\hline $\begin{array}{l}\text { Case } \\
\text { No }\end{array}$ & $\begin{array}{l}\text { Duration } \\
\text { (months) }\end{array}$ & $\begin{array}{l}\text { Sample| } \\
\text { isolate }\end{array}$ & Mucoid & Serotype & Titre \\
\hline 1 & $6^{\star}$ & $\begin{array}{l}1 \\
2 \mathrm{a} \\
2 \mathrm{~b}\end{array}$ & $\begin{array}{l}- \\
+ \\
-\end{array}$ & $\begin{array}{l}09 \\
\text { Polyagglutinable } \\
\text { Polyagglutinable }\end{array}$ & $\begin{array}{r}2000 \\
4000 \\
500\end{array}$ \\
\hline 2 & $\begin{array}{l}2 \\
4 \\
5 \\
6 \\
7 \\
9 \star\end{array}$ & $\begin{array}{l}\mathrm{a} \\
1 \mathrm{~b} \\
1 \mathrm{c} \\
2 \mathrm{a} \\
2 \mathrm{~b} \\
3 \\
4 \\
5 \mathrm{a} \\
5 \mathrm{~b} \\
6 \mathrm{a} \\
6 \mathrm{~b} \\
7 \mathrm{a} \\
7 \mathrm{~b}\end{array}$ & $\begin{array}{l}+ \\
- \\
- \\
+ \\
+ \\
+ \\
+ \\
+ \\
+ \\
+ \\
- \\
-\end{array}$ & $\begin{array}{l}06 \\
06 \\
06 \\
06 \\
06 \\
06 \\
06 \\
\text { Polyagglutinable } \\
\text { Polyagglutinable } \\
\text { Polyagglutinable } \\
\text { Unclassifiable } \\
06 \\
\text { Polyagglutinable }\end{array}$ & $\begin{array}{r}1500 \\
2000 \\
8000 \\
6000 \\
3000 \\
16000 \\
8000 \\
64000 \\
4000 \\
30000 \\
4000 \\
12000 \\
6000\end{array}$ \\
\hline 3 & $\begin{array}{c}1 \\
2^{\star}\end{array}$ & $\begin{array}{l}1 \mathrm{a} \\
1 \mathrm{~b} \\
1 \mathrm{c} \\
2 \mathrm{a} \\
2 \mathrm{~b} \\
2 \mathrm{c}\end{array}$ & $\begin{array}{l}+ \\
- \\
+ \\
- \\
-\end{array}$ & $\begin{array}{l}\text { Polyagglutinable } \\
\text { Non-typable } \\
\text { Non-typable } \\
\text { Polyagglutinable } \\
\text { Polyagglutinable } \\
\text { Polyagglutinable }\end{array}$ & $\begin{array}{r}1500 \\
6000 \\
4000 \\
8000 \\
10000 \\
8000\end{array}$ \\
\hline
\end{tabular}

^Serum sample taken. antigens. ${ }^{11}$ Heavily mucoid or dry colonies which could not be emulsified in saline were not examined further. Twenty one patients also harboured 0-typable strains and the serotypes found in order of prevalence were $06(n=7)$, $03(n=5), 09(n=3), 011(n=2) 01(n=2)$, 02 and 010 ( $n=1$ of each). One patient harboured two strains of different serotypes.

Table 1 gives the mean and range of ELISA titres of the 60 fibrocystic sera and the six control sera with, where appropriate, 0 -typable and 0-defective homologous isolates, or the serotype strain 06 that was included as a reference control. Each of the control sera gave titres of 400 or less and the maximum titre obtained with a colonised patient's serum was 64000 . The mean titres of colonised patients with both groups of isolates were similar but patients who were continuously colonised (more than three years) gave titres generally two fold higher than those recently colonised; a wider range of titres was also found in the former group. Overall, patients had higher titres against 0 -typable than 0 -defective strains, but this was reversed for patients recently colonised with Ps aeruginosa. One of the non-colonised patients gave a titre of 6400 with both strain 06 and a reference 0 -defective variant, ${ }^{11}$ and two others had titres of 1000 with strain 06 but were within normal limits of the 0 -defective strain.

It was clear that a cut-off of clinically important titre, which would distinguish between newly colonised and persistently colonised patients, could not be selected. Furthermore, as an average of six isolates was recovered from each of the 54 patients positive for Ps aeruginosa it was necessary to examine in detail the antibody titres of selected patients with each of their isolates recovered at the time of the serum sample or before that date. Immunoblotting of LPS extracts separated by SDS-PAGE was also performed to identify differences in antibody binding with LPS constituents.

Case 1 (table 2) had first been colonised about six months before the serum collection date with a serotype 09 non-mucoid strain. When the serum sample was taken two polyagglutinating variants of mucoid and nonmucoid colonial forms were isolated. The highest ELISA titre was recorded for the mucoid $P s$ aeruginosa variety, although the response to the original 09 strain was similar; the second Ps aeruginosa variant gave a much lower titre. Type specific antibody, judged by the response to the serotype 09 reference strain, was of a similar titre to that obtained with the homologous 09 strain.

Silver stains of the LPS profiles of isolates from case 1 (fig 1a) showed numerous densely stained bands in the upper part of the gel of the 09 isolates, corresponding to high molecular weight 0 repeating units of LPS. Isolates $2 a$ and $2 \mathrm{~b}$ contained only low molecular weight LPS core components, evidenced by the lack of bands in the upper gel. The corresponding immunoblot with this patient's serum (fig 1b) showed antibody binding to the ladder bands, but no reaction with LPS core components of any of the isolates was visible. 


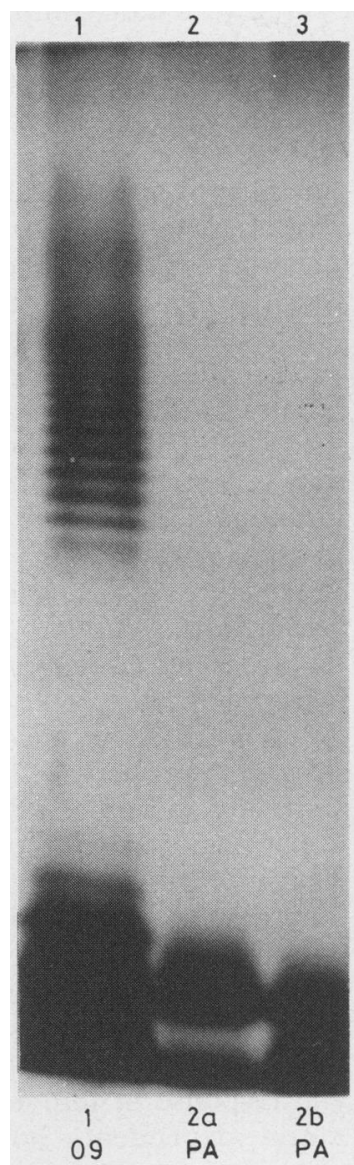

(A)

Figure 1a Silver stain of LPS extracts of isolates from case 1 after SDS-PAGE.

Figure $1 \mathrm{~b}$ Immunoblot with homologous serum diluted 1 in 1000.
In contrast, case 2 had had Ps aeruginosa for seven years and 13 isolates recovered over eight months before the serum collection dates were available. Table 2 shows that the ELISA titre for the serotype 06 strain ranged from 1500 to 16000 and the titre varied towards the same 0 serotypable phenotype in different samples. For example, the titre with the isolate la was about 10-fold lower than that with isolate 3 . Variation in titre was also found with 0 -defective strains, as shown with isolates $5 \mathrm{a}$ (64000) and $5 \mathrm{~b}$ (4000) from the same specimen.

SDS-PAGE of 10 isolates showed that despite the lack of specificity in agglutination tests only one of the $P s$ aeruginosa strains (5b) was grossly deficient in high and medium molecular weight LPS components (fig 2a). Furthermore, antibody binding to LPS core and lipid A was either extremely weak or nonexistent when compared with bands formed by antibody to other LPS components.

Case 3 had also persistently harboured $P s$ aeruginosa for at least seven years and the six isolates recovered over two months were serologically atypical and two of them were mucoid (table 2). The titres ranged from 1500 to 10000 and no association between the phenotype of the isolate and titre was evident. SDS-PAGE showed variation in LPS banding pattern, as found with other patients' isolates, and immunoblotting showed weak antibody binding only to high molecular weight LPS. This pattern of reactivity to different titres with various isolates was repeated in a further six serum samples and similar immunoblot profiles were obtained.

\section{Discussion}

Brett et al showed that an ELISA test with

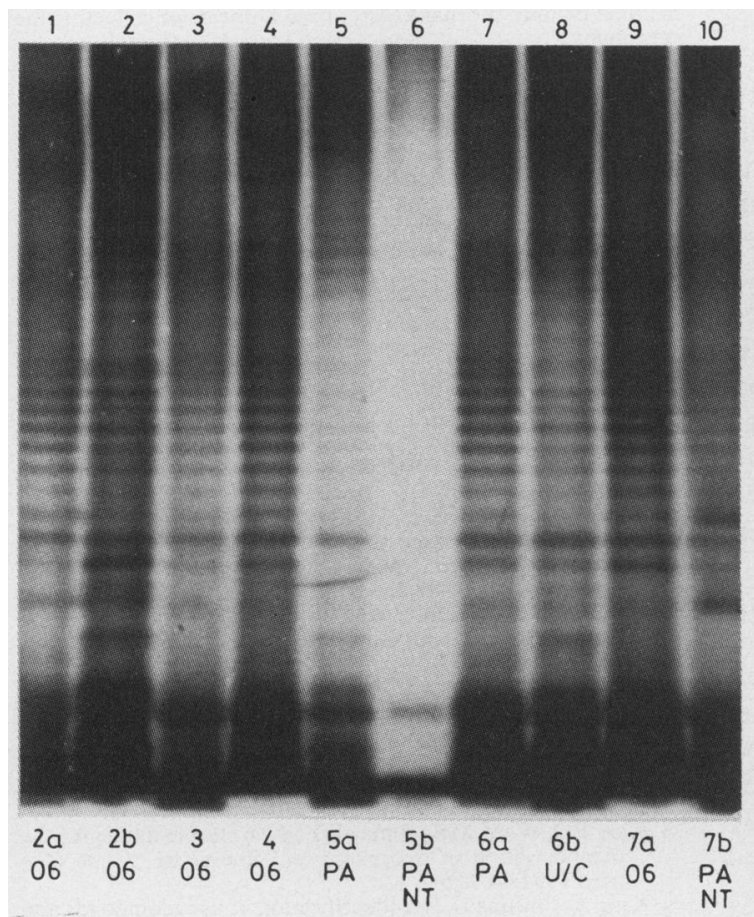

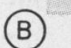

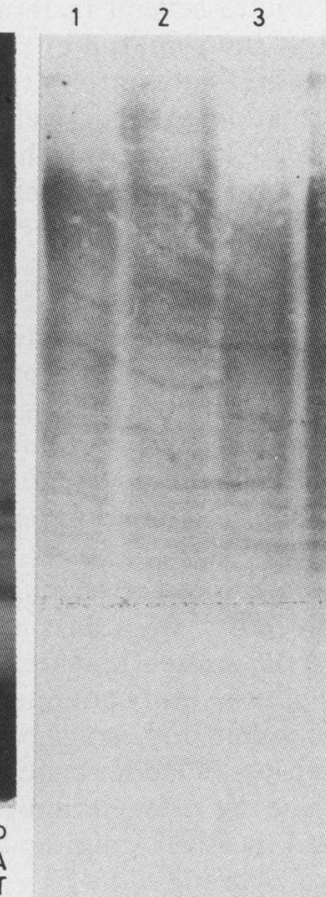

$\begin{array}{llllll}5 & 6 & 7 & 8 & 9 & 10\end{array}$

Figure $2 a$ Silver stain of LPS extracts of isolates from case 2 after SDS-PAGE.

Figure $2 b \quad$ Immunoblot with homologous serum diluted 1 in 1000. 
whole cells of standard strains of Ps aeruginosa could be used to measure serum IgG antibodies to cell surface antigens in paediatric fibrocystic patients and that titres were correlated with the stage and severity of infection. ${ }^{16} \mathrm{We}$ began this study with the view that because many of the strains of $P$ s aeruginosa from adult patients are defective in the synthesis of 0-repeating units which confer serotype specificity, it was probably inappropriate to use strains in the ELISA that would not be representative of those commonly isolated from patients.

We classified isolates from patients according to their serotype and found that those who had been culture positive for several years generally gave higher titres with both 0 -specific and 0 -defective strains than those who had been recently colonised. This contrasts with the findings of a recent study which concluded that the specificity of the antibody response with Pseudomonas LPS increased with the duration of infection. ${ }^{17}$ We were unable to study sequential sera, however, and did not differentiate between IgG and IgM antibody; the latter is apparently similar in concentration in chronic and non-colonised fibrocystic patients. ${ }^{17}$ Nevertheless, we can confirm that non-colonised patients seldom had higher titres of antibody against either antigenic variety of $P s$ aeruginosa and were only marginally above those of controls.

Serum titres towards sequential isolates of individual patients showed that the antibody response was highly strain dependent, but the magnitude of titres did not correlate with the 0 antigenic state of the isolates. Brett $e t$ al found that the laboratory strain of the serotype that produced the highest ELISA titre with a patient's serum sample was not always the same serotype as the sputum isolate. ${ }^{16}$ They reasoned that this was probably due to several factors, including failure to detect the serotype in the patient's sputum, antibiotic treatment, or the delay of serum IgG formation. Alternatively, antibody may be directed against other antigenic structures such as outer membrane proteins which are antigenically conserved. One might expect, however, that the antibody titre of a single serum sample with a variety of strains would be similar if the antibody reacted with a conserved antigen. Moreover, the conserved outer membrane protein antigens are highly immunogenic and in rabbits produce titres far in excess of those engendered by LPS, and titres are reproducible with different strains. ${ }^{18}$

SDS-PAGE showed that minor variations in LPS banding profile resulted in a loss of serotype specificity as some strains that were Ps aeruginosa by slide agglutination contained 0-repeating units while other Ps aeruginosa strains showed a complete loss of ladder bands. Nevertheless, immunoblotting often illuminated 0-bands not detected by silver staining; a feature also observed by Cochrane et al. ${ }^{19}$

Immunoblots of LPS extracts of sequential isolates from three patients confirmed the antigenic activity of LPS in vivo, and the contrast in the intensity of antibody binding to high and medium molecular weight LPS, com- pared with core components was quite noticeable. Hancock et al reported that $74 \%$ of chronically infected fibrocystic patients had antibody that bound to core LPS ${ }^{20}$ and a recent Danish study seems to support this. ${ }^{17}$ Our inability to detect clinically important antibody binding to core LPS may be a reflection of our methodology, but we consider this unlikely as positive blots with core LPS with hyperimmune rabbit sera had been obtained in routine tests. In our experience core LPS strains are less immunogenic than those with complete LPS and therefore may give rise to lower antibody reactivity in ELISA and immunoblotting. The response of both of the persistently colonised patients may have been directed mainly towards the more immunogenic portions of the LPS.

Jacobsen et al suggested that antibodies to $P S$ aeruginosa core LPS were present in chronic but not acute Pseudomonas infection, and 11 of 18 fibrocystic patients had demonstrable serum antibody to core LPS. $^{21}$ Further studies are clearly needed with purified and chemically characterised LPS constituents to identify the importance of antibody responses to various regions of the molecule.

We conclude that an ELISA method with whole bacterial cells is a sensitive measure of serum antibody in cystic fibrosis. The titre of the response of individual patients' serum is strain dependent, however, and does not correlate with the 0 -antigen composition of the isolate. Our data therefore question the use of standard laboratory strains in the ELISA and we suggest that a variety of isolates recovered from the sputum should be tested individually to determine the range of titres of patients' sera.

This work was supported by the Cystic Fibrosis Research Trust of Great Britain. We thank Sister Fran Duncan for collecting the specimens.

1 Brett MM, Ghoneim ATM, Littlewood JM. Serum antibodies to Pseudomonas aeruginosa in cystic fibrosis. arch Dis Child 1986;61:1114-20.

2 Pedersen SS, Espersen F, Hoiby N. Diagnosis of chronic Pseudomonas aeruginosa infection in cystic fibrosis by enzyme-linked immunosorbent assay. J Clin Microbiol 1987;25:1830-6.

3 Jagger KN, Robinson DL, Franz MN, Warren RL. Detection by enzyme-linked immunosorbent assays of antibody specific for Pseudomonas proteases and exotoxin $A$ in sera from cystic fibrosis patients. J Clin Microbiol 1982; 15:1054-8.

4 Brett MM, Ghoneim ATM, Littlewood JM. Prediction and diagnosis of early Pseudomonas aeruginosa infection in cystic fibrosis: a follow up study. J Clin Microbiol cystic fibrosis: a

5 Hollsing AE, Granstrom M, Vasil ML, Wretlind B, Strandvik B. Prospective study of serum antibodies to Pseudomonas aeruginosa exoproteins in cystic fibrosis. $J$ Clin Microbiol 1987;25:1868-74.

6 Chester IR, Meadow PM, Pitt TL. The relationship between the 0 -antigenic lipopolysaccharides and serological specificity in strains of Pseudomonas aeruginosa of different 0-serotypes. J Gen Microbiol 1973;78:305-18.

7 Hancock REW, Mutharia LM, Chan L, Darveau RP, Speert D, Pier GB. Pseudomonas aeruginosa isolates from patients with cystic fibrosis: a class of serum sensitive non typable strains deficient in lipopolysaccharide 0 side typable strains deficient in lipopolys

8 King EO, Ward MK, Raney DE. Two simple media for the demonstration of pyocyanin and fluorescin. J Lab Clin Med 1954;44:301-7.

9 King A, Phillips I. The identification of pseudomonads and related bacteria in a clinical laboratory. $J$ Med Microbiol 1978;11:165-76.

10 Liu PV, Matsumoto H, Kusama H, Bergan T. Survey of heat-stable major somatic antigens of Pseudomonas aeruginosa. Int $J$ Syst Bacteriol 1983;33:256-64

11 Pitt TL, MacDougall J, Penketh ARL, Cooke EM. Polyagglutinating and non-typable strains of Pseudomonas 
aeruginosa in cystic fibrosis. $J$ Med Microbiol 1986;21:179-86.

12 Hitchcock PJ, Brown TM. Morphological heterogeneity among Salmonella lipopolysaccharide chemotypes in
silver stained polyacrylamide gels. J Bacteriol 1983;

154:269-77.

Laemmli UK. Cleavage of structural proteins during the assembly of the head of bacteriophage T4. Nature 1970;227:680-5.

14 Tsai CM, Frasch CE. A sensitive silver stain for detecting lipopolysaccharides in polyacrylamide gels. Anal Biochem 1982;119:115-19.

15 Gaston MA, Duff PS, Pitt TL. Lipopolysaccharide heterogeneity in strains of Serratia marcescens agglutinated by 014 antiserum. Curr Microbiol 1988;17:27-31.

16 Brett MM, Ghoneim ATM, Littlewood JM, Losowsky MS. Development of enzyme linked immunosorbent assay (ELISA) to detect antibodies to Pseudomonas aeruginosa cell surface antigens in sera of cystic fibrosis patients. $J$ cell surface antigens in sera
17 Fomsgaard A, Hoiby N, Shand GH, Conrad RS, Galanos C Longitudinal study of antibody response to lipopolysaccharides during chronic Pseudomonas aeruginosa lung infection in cystic fibrosis. Infect Immun 1988;56:2270-8.

18 MacDougall J. A study of Pseudomonas aeruginosa from adult CF patients. [PhD Thesis] University of London, 1987:134.

19 Cochrane DMG, Brown MRW, Weller PH. Lipopolysaccharide antigens produced by Pseudomonas aeruginosa from cystic fibrosis lung infection. FEMS Microbiol Lett 1988;50:241-5.

20 Hancock REW, Mouat ECA, Speert DP. Quantitation and identification of antibodies to outer membrane proteins of Pseudomonas aeruginosa in sera of patients with cystic fibrosis. J Infect Dis 1984;149:220-6.

21 Jacobson MA, Radolf JD, Young LS. Human IgG antibodies to Pseudomonas aeruginosa core lipopolysaccharide determinants are detected in chronic but not acute pseudomonas infection. Scand J Infect Dis 1987;19: pseudom 60 . 